\title{
РАДИОЛЯРИИ ИЗ ВЕРХНЕГО ОРДОВИКА ЭСТОНИИ
}

C применением метода химического препарирования при изучении кислотоустойчивых микрофоссилий (в основном хитинозой) из верхнеордовикских (=ашгиллских; см. Решения..., 1978) отложений Эстонии были обнаружены и раковины радиолярий. Всего обработано около 1000 проб из кернов 22 буровых скважин и 2 обнажений, расположенных на территории Эстонии, однако радиолярии обнаружены только в нескольких пробах из разрезов скважин Эйкла, Каугатума (о. Сааремаа) и Вильянди (см. рисунок).

Схема расположения буровых скважин, в которых найдены радиолярин.

Поскольку эта первая находка радиолярий из разрезов Эстонии и вообще из коренных платформенных отложений раннего палеозоя Русской платформы, то авторы сочли

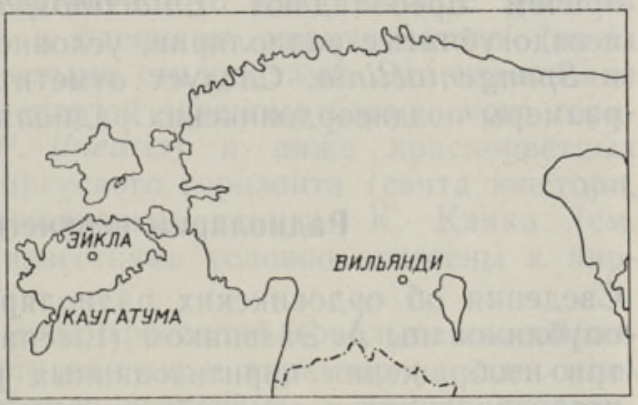
необходимым описать собранную, хотя и очень немногочисленную коллекцию радиолярий, состоящую из 26 целых экземпляров и фрагментов раковин удовлетворительной сохранности, которые хранятся в Институте геологии АН ЭССР.*

Фотографии радиолярий выполнены Е. Климовым в Институте геологии АН ЭССР на сканирующем электронном микроскопе MSM-2 фирмы «Акаси» (Япония).

\section{О распространении ордовикских рациолярий}

Впервые ордовикские радиолярии были описаны в конце прошлого столетия Дж. Хайндом (Hinde, 1890) из лландейло-карадока Южной Шотландии. Однако данные, которые можно использовать для стратиграфии, были получены только за последние годы. Радиолярии хорошей сохранности были выделены из ордовикских отложений многих регионов земного шара. В настоящее время радиолярии раннего ордовика известны из формаций Вальхальфонна (премадок-арениг) Шпицбергена (Fortey, Holdsworth, 1971), Тейбл Хэд (арениг) Ньюфаундленда 'Bergström, 1974) и кызылжарской свиты (арениг-лланвирн?) Центтьного Казахстана (Назаров, Попов, 1980). Радиолярии среднего 2. зика описаны из бестамакской свиты (лландейло-нижний карадок)

* Bu время подготовки статьи к печати дополнительно найдено 80 экземпляров радиолярий с гидрогетитовым скелетом и сходным видовым составом из скрытокристаллических известняков сауньяской пачки (обнажение в окрестности г. Тапа). 
Восточного Казахстана (Назаров, 1975; Назаров, Пॉопов, 1980). П̈редположительно ореднеордовикские радиолярии обнаружены в формации Юошики в Центральной Японии (Igo и др., 1980). Позднеордовикские радиолярии известны из формации Хэнсон Крик (карадок) Северной Америки (Duncham, Murphy, 1976) и улькунтасских известняков (ашпилл) Центрального Казахстана (Назаров, Попов, 1980).

Радиолярии ордовика представлены преимущественно сферическими полицистинами с внутренним каркасом, хорошо развитыми одной-двумя сферическими, в основном пористыми, оболочками и массивными стержневидными иглами. Они относятся к семейству Entactiniidae s. str. Реже встречаются билатерально-симметричные радиолярии (Ceratoikiscidae, Palaeoscenidiidae).

В раннем ордовике распространены Entactinia, Entactinosphaera, Helioentactinia, Haplentactinia, Popofskyellum?. Встречаются первые представители своеобразных радиолярий Auakrusidae (i. s.). Радиолярии среднего ордовика более разнообразны. Все роды известные в раннем ордовике, за исключением Popofskyellum?, продолжают свое существование и в среднеордовикскую эпоху. В это время появляются многочисленные Pylentonema, а также Syntagentactinia, Auliella, Ceratoikiscum?, Polyentactinia. Радиолярии позднего ордовика менее разнообразны. По-прежнему основную пруппу составляют Entactiniidae, причем преобладают Entactinosphaera, Haplentactinia, появляются псевдогубчатые радиолярии, условно отнесенные к родам Tetrentactinia и Spongentactinia. Следует отметить несколько меньшие (в среднем) размеры позднеордовикских радиолярий.

\section{Радиолярии верхнего ордовика Эстонии}

Сведения об ордовикских радиоляриях Балтоскандии впервые были опубликованы А. Эйзенаком (Eisenack, 1971, рис. 48-50). Он приводит три изображения пиритизованных раковин спумеллярий (без детального описания) и отмечает их удовлетворительную сохранность, а также трудности при их препарировании. А. Эйзенак обнаружил радиолярии в эрратических валунах, представленных светлыми скрыто-кристаллическими известняками (кальцилютитами). По граптолоидеям и хитинозоям, найденным из тех же валунов (см. Eisenack, 1965, 1967, 1971), их возраст, по-видимому, соответствует верхам среднего (раквереский горизонт) или низам верхнего ордовика (набалаский горизонт).

Описанные в данной статье радиолярии приурочены к двум стратиграфическим уровням: сауньяской пачке набалаского горизонта (F $\mathrm{F}$ S $)$ и пограничным слоям вормсиского и пиргуского горизонтов $\left(\mathrm{F}_{\mathrm{I}} \mathrm{b} / \mathrm{F}_{\mathrm{I}} \mathrm{c}\right)$. Характерной особенностью позднеордовикских радиолярий Эстонии является замещение их кремнистого скелета пиритом или гидрогетитом.

1. В разрезах скважин Эйкла и Каугатума радиолярии найдены в отложениях сауньяской пачки набалаского горизонта (= $=$ она $P$. linearis; см. Мянниль, 1976). Эта пачка сложена желтовато-белыми скрытокристаллическими волнисто-среднеслоистыми известняками с редким мелким детритом, для которых типичны темно-серые пиритизованные пятна и разводы (в скв. Каугатума только местами) и тонкие волнистые прослойки коричневато-серого известкового мергеля. Из керна скв. Эйкла (инт. 275,4-286,0 м) обработаны 12 проб (средним весом около 300 г породы), однако только 5 из них содержали остатки радиолярий; а из скв. Каугатума (инт. $387,1-407,4$ м) из 16 проб только в 2-х найдено несколько фрагментов Entactiniidae gen. et sp. indet. Первичный скелет всех найденных радиолярий замещен пиритом. Другие группы кислотоустойчивых микрофоссилий в этих пробах представлены хити- 
нозоями (до 14 видов), сикулами и редкими рабдосомами граптолоидей (Climacogiaptus), сколекодонтами (Polychaetaspis, Skalenoprion и др.), фораминиферами (Blastammina, Psammosphaera, Amphitremoida и др.); редкими меланосклеритами и стеблевыми остатками иглокожих, спикулами губок (кальцитовые или пиритизованные), дендроидеями; единичными беззамковыми и частично окремнелыми остатками замковых брахиопод и очень редкими акритархами (Leiosphaeridia, Baltisphaeridium, Tasmanites).

Необходимо отметить сходство этих пород (и их микрофоссилий) с изученными А. Эйзенаком эрратическими валунами (Eisenack, 1965, 1967, 1971; валуны под номерами S. G. 65 и 101).

Перечисленная ассоциация ископаемых органических остатков из разрезов скважин Эйкла и Каугатума показывает, что вмещающие отложения, по-видимому, образовались в условиях открытого шельфа (см. также Мянниль, 1966).

2. В разрезе скв. Вильянди радиолярии найдены в маломощной пачке, залегающей в интервале $308,5-310,5$ м. Они обнаружены только в одной из 7 отобранных проб (средним весом 500 г породы). Скелеты состоят из гидрогётита (определение К. Менс).

Пачка сложена из серовато-желтого скрытокристаллического от среднеслоистого до мелкокомковатого детритистого известняка, с тонкими и очень волнистыми прослойками и пленками коричневатого (из-за содержания гётита) мергеля и с частыми стилолитами. Эти известняки залегают выше зеленовато-серых мергелей заведомо вормсиского горизонта (свита тудулинна, $=$ зона P. linearis) и ниже красноцветных глинистых известняков заведомо пиргуского горизонта (свита юнсторп, $=$ зсна D. complanatus). По рукописным данным K. Каяка (см. А. Ораспыльд, 1975; рис. 6), эти известняки условно отнесены к пиргускому горизонту.

Ассоциация кислотоустойчивых микрофоссилий довольно своеобразна - отсутствуют широко распространенные и характерные для отложений вормсиского и пиргуского времен бентосные фоссилии: сколекодонты, фораминиферы, меланосклериты, а также акритархи и хитинозои. Отсутствие хитинозой нетипично для пограничных слоев названных горизонтов (см. Nõlvak, 1980; рис. 2). В то же время здесь обнаружен исключительно богатый комплекс микроскопических беззамковых брахиопод (9 родов) и конодонтов (5 видов). Кроме того, довольно часто встречаются стеблевые остатки иглокожих и спикулы губок. Такая ассоциация микрофоссилий указывает на своеобразные условия во время осадконакопления. Отсутствие каких-либо известных руководящих форм (например, хитинозой) затрудняет более точное определение возраста вышеописанных известняков.

Из приведенных А. Эйзенаком (Eisenack, 1971) и нами данных следует, что в отложениях, по крайней мере верхнего ордовика Балтийского бассейна, находки радиолярий связаны исключительно со скрытокристаллическими известняками (кальцилютитами). Данный тип по сравнению с глинистыми разновидностями пород оказывается более благоприятным для сохранения хрупких раковин радиолярий. Учитывая спорадическое распространение остатков радиолярий в ордовикских отложениях Балтийского бассейна (единичные экземпляры в скрытокристаллических известняках верхнего ордовика), они не имеют здесь существенно корреляционного значения, однако, представляют интерес в экологическом аспекте.

Описанные радиолярии представлены типично ордовикскими видами, которые можно отнести к родам Entactinia, Haplentactinia, Polyentactinia и Astroentactinia?. По морфологии и размерам радиолярии из верхнего ордовика Эстонии, особенно представители Entactinia и 
Haplentactinia, очень сходны с некоторыми радиоляриями, изображения которых приведены Д. Б. Данхамом и М. А. Мэрфи (Duncham, Murphy, 1976) из карадока Невады, а также с Haplentactinia sp. из улькунтасских известняков $\left(\mathrm{O}_{3}\right)$ Чу-Илийских гор и Entactinia cf. unica из яшм баварбайской свиты $\left(\mathrm{O}_{2-3}\right)$ гор Тектурмас в Казахстане.

\title{
Описания
}

\author{
Отряд Polycystina \\ Подотряд Spumellaria
}

Семейство Entactiniidae Riedel, 1967

Подсемейство Entactiniinae Riedel, 1967, emend Nazarov, 1975

Род Entactinia Foreman, 1963

Entactinia eiklaensis Nazarov, sp. $\mathrm{n}$.

Табл. I, фиг. $1-3$

Гол оти п. R1/5408, табл. I, фиг. 1-2. Скв. Эйкла, гл. 279,5 м, Эстония. Верхний ордовик (ашгилл), сауньяская пачка набалаского горизонта $\left(\mathrm{F}_{\mathrm{I}} \mathrm{SS}\right)$.

О пи сание. Небольшие сферические Entactinia с эксцентрично расположенным внутренним каркасом. Основные иглы, являющиеся непосредственным продолжением лучей внутреннего каркаса, конусовидные, равномерно сужающиеся от основания к дистальной части: Второстепенные иглы различной длины. Оболочка раковины неравномерно пронизана угловато-овальными порами различного диаметра. Внутренний каркас представлен, по-видимому, полым, округленным гексаэдром, от углов которого отходят шесть полых, иногда изогнутых лучей.

Р а з меры (в микронах). Диаметр сферы 94-217, толщина стенки до 10 , длина основных игл до 180 , диаметр их в основании $16-20$, длина второстепенных игл до 23, диаметр пор 4-18 (в среднем $10-12)$.

С ра внени е. От большинства известных в настоящее время ордовикских Entactinia spp. описываемый вид отличается весьма эксцентричным расположением внутреннего каркаса и небольшими размерами. Небольшие размеры и стержневидные иглы имеют радиолярии, изображенные, но не названные Д. Б. Данхамом и М. А. Мэрфи (Duncham, Murphy, 1976, с. 886 , табл. 1, фиг. 7-8), однако у описываемого вида более толстая стенка и имеются второстепенные иглы, которые, по-видимому, отсутствуют у полицистин из позднего ордовика Невады.

Р асппостр анение. Верхний ордовик (ашгилл), сауньяская пачка набалаского горизонта ( $\left.\mathrm{F}_{\mathrm{IaS}}\right)$ Эстонии.

Местонахождение и м а тери ал. Скв. Эйкла, глубины 278,5 и 279,5 м; 3 экземпляра.

ТАБЛИЦА I

Фиг. 1-3. Entactinia eiklaensis Nazarov, sp. n. 1 - голотип, R1/5408, $\times 250 ; 2$ то же, Х620. Скв. Эйкла, гл. 279,5 м, $3-\mathrm{R} 6 / 5409, \times 130$. Скв. Эйкла, гл. 278,5 м, сауньяская пачка набалаского горизонта.

Фиг. 4. Astroentactinia sp.? R3/5405, $\times 440$. Скв. Эйкла, гл. 282,5 м, сауньяская пачка набалаского горизонта. 


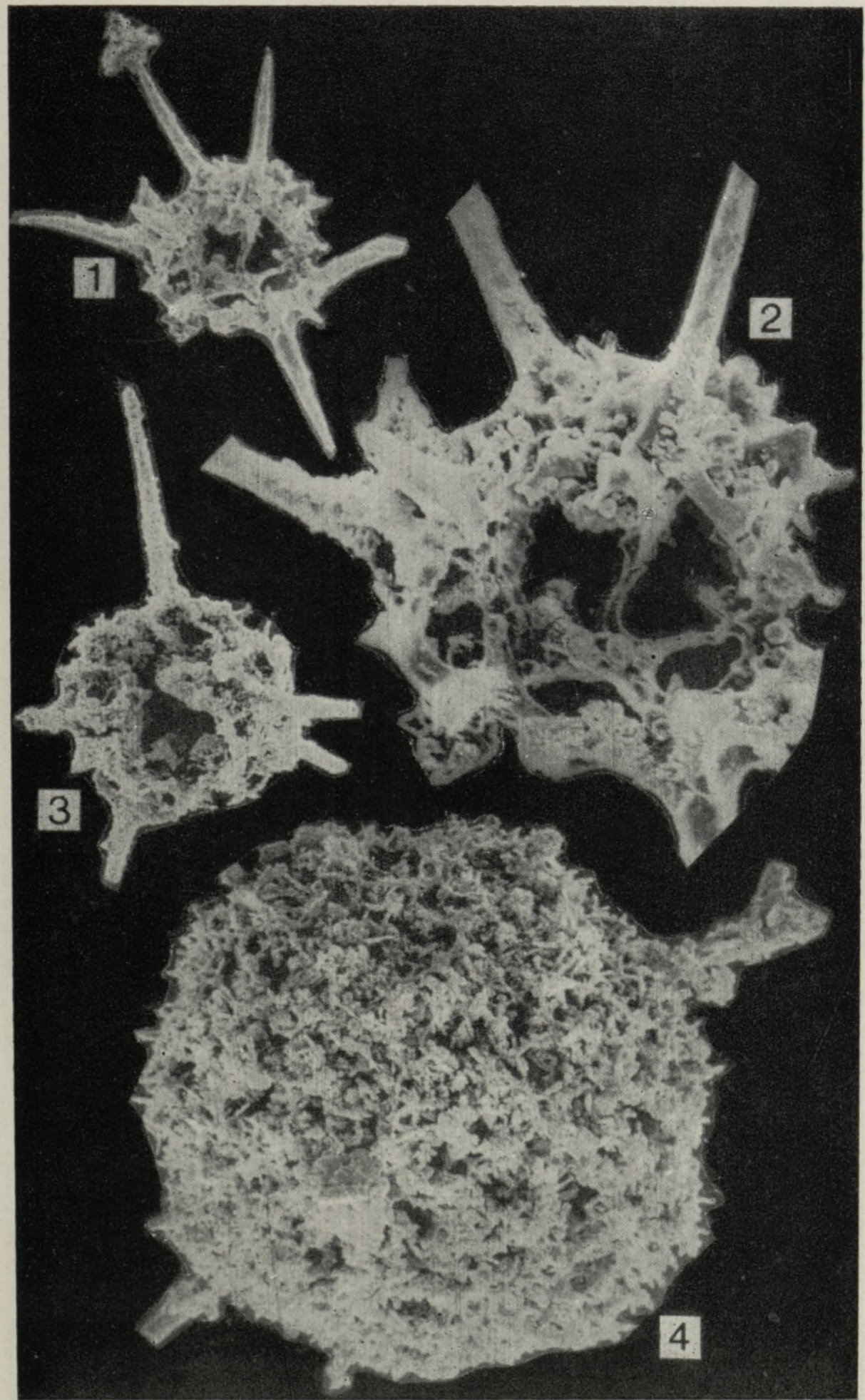




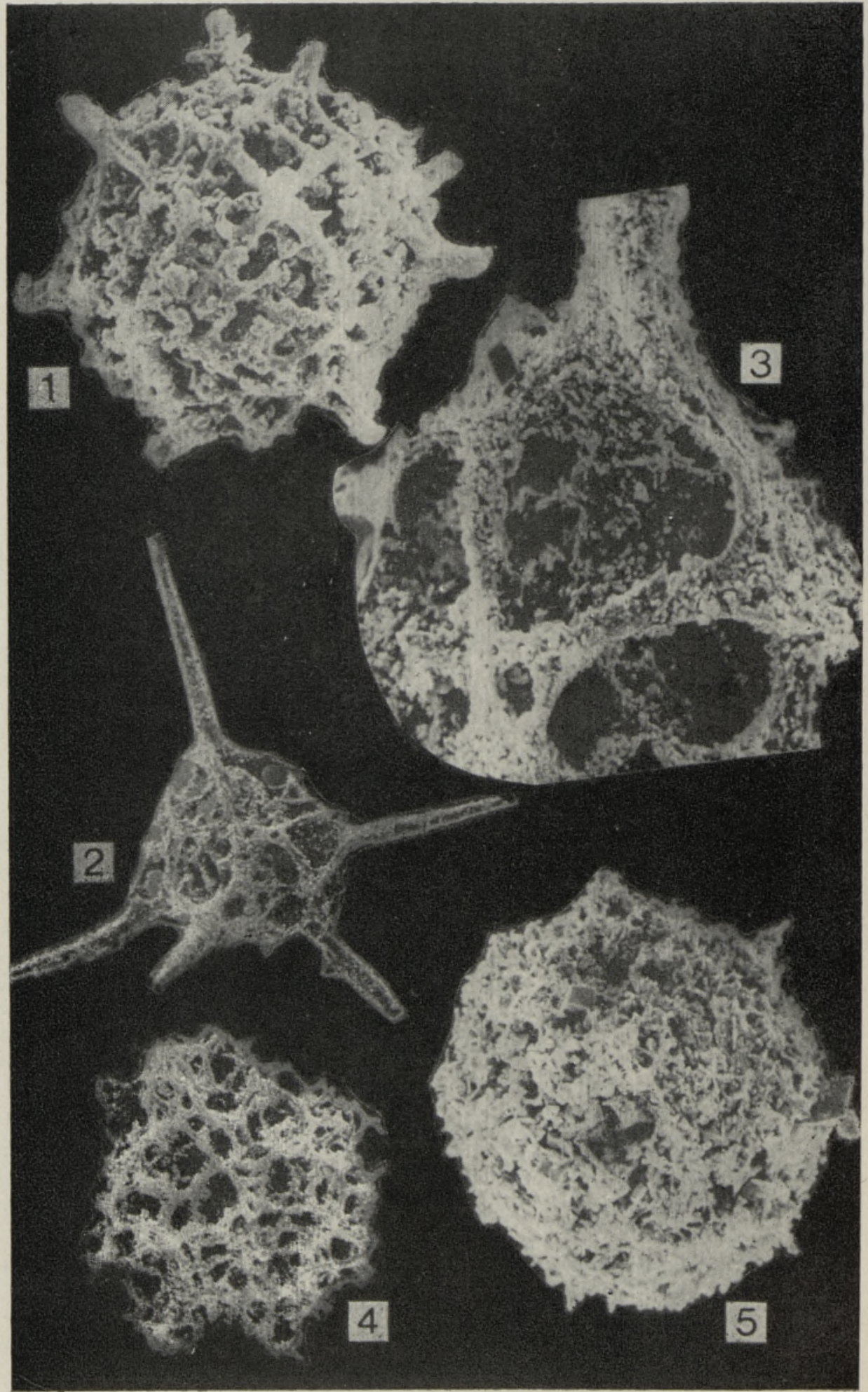


Подсемейство Haplentactiniinae Nazarov, 1980

Род Haplentactinia Foreman, 1963

Haplentactinia baltica Nazarov, sp. n.

Табл. II, фиг. 2-4

Haplentactinia sp. - Назаров, Попов, 1980, с. 55-56, табл. XVII, фиг. 4.

Голоти п. R2/5408, табл. II, фиг. 2-3. Скв. Эйкла, гл. 279,5 м, Эстония. Верхний ордовик (ашгилл), сауньяская пачка набалаского горизонта $\left(\mathrm{F}_{\mathrm{IaS}}\right)$.

Оп и сание. Неправильно-сферическая крупная раковина с шестью массивными конусовидными иглами. Эти иглы, по-видимому, являются непосредственным продолжением лучей внупренней спикулы. Приблизительно на одинаковом расстоянии от центра иглы разветвлены, и образующиеся в данном месте апофизы всех игл соединяются, образуя изометричную раковину с крупными ячеями.

Р а змер ы (в микронах). Диаметр раковины 182-196 (до 300), длина игл до 330 , диаметр игл в основании $14-20$, диаметр ячей до 50.

С р а в нен и е. Описываемый вид весьма сходен с Haplentactinia juncta из ореднеордовикских отложений Восточного Казахстана, от которого отличается конусовидными иглами и более крупными ячеями. Можно отметить несколько меньшие размеры описываемого вида.

3 а меч ания. В позднеордовикских отложениях Центрального Казахстана был обнаружен единственный экземпляр крупноячеистой раковины с одной стержневидной иглой, описанный 'как Haplentactinia sp. (Назаров, Попов, 1980, с. 55-56). Крупные ячеи, образующиеся особенно у игл, имеет и описываемый вид, что в какой-то мере свидетельствует о их сходстве, и по-видимому, экземпляр $H$. sp. из Қазахстана можно рассматривать как $H$. baltica.

Р ас пр остранение. Верхний ордовик (ашгилл), сауньяская пачка набалаского горизонта ( $\left.\mathrm{F}_{\mathrm{I}} \mathrm{SS}\right)$ Эстонии и улькунтасские известняки Центрального Казахстана.

Местонахождение и м а тери ал. Скв. Эйкла, глубина 279,5 и 280,5 м; 1 целый экземпляр и несколько фрагментов раковин.

Подсемейство Polyentactiniinae Nazarov, 1975

Род Polyentactinia Foreman, 1963

Polyentactinia? estonica Nazarov, sp. n.

Табл. II, фиг. 1

Г ол о ти п. R8/7074, табл. II, фиг. 1. Скв. Вильянди, гл. 310,1 м, Эсто-

ТАБЛИЦА II

Фиг. 1. Polyentactinia? estonica Nazarov, sp. n. голотип, R8/7047, $\times 440$. Скв. Вильянди, гл. 310,1 м, пограничные слои вормсиского и пиргуского горизонтов.

Фиг. 2 -4. Haplentactinia baltica Nazarov, sp. n. $2-$ голотип, R2/5408, $\times 130 ; 3-$ то же, $\times 620$. Скв. Эйкла, гл. 279,5 м, сауньяская пачка набалаского горизонта; $4-$ $\mathrm{R} 5 / 5407, \times 130$. Скв. Эйкла, гл. 280,5 м, сауньяская пачка набалаского горизонта.

Фиг, 5. Astroentactinia sp.? R4/5405, $\times 440$. Скв. Эйкла, гл. 282,5 м, сауньяская пачка набалаского горизонта. 
ния. Верхний ордовик (ашгилл), пограничные слои вормсиского и пиргуского горизонтов $\left(\mathrm{F}_{\mathrm{I}} \mathrm{b} / \mathrm{F}_{\mathrm{Ic}} \mathrm{c}\right)$.

О пис ание. Раковина сферическая с многочисленными короткими основными иглами, расширенными в основании. Второстепенные иглы выражены в виде небольших приостренных зубчиков на перекладинах межпоровой решетки. Почти все основные иглы соединены между собой утолщенными стержнями, вследствие чего оболочка как бы разделена на довольно правильные сегменты. Каждый сегмент в свою очередь разделен дополнительными перекладинами, в результате чего образуется пористая внешняя оболочка. Строение внутреннего каркаса не ясно.

Р а з меры (в микронах). Диаметр сферы 105-110, толщина стенки $8-10$, диаметр пор до 18 , длина основных игл $14-24$, диаметр их в основании до 20, длина второстепенных игл до 6.

С р а внение. Описываемый вид сходен с P. offerta из среднего ордовика Восточного Казахстана, от которого отличается массивными перекладинами, соединяющими основания игл, слаборазвитыми второстепенными иглами и довольно однообразной формой пор.

Р а сп ространени е. Верхний ордовик (ашгилл), пограничные слои вормсиского и пиргуского горизонтов $\left(\mathrm{F}_{\mathrm{I}} \mathrm{b} / \mathrm{F}_{\mathrm{Ic}} \mathrm{c}\right)$, Әстония.

Местонахождени е и м а тери ал. Скв. Вильянди, глубина 310,1 м; 1 целый экземпляр и несколько фрагментов раковин.

\section{Род Astroentactinia Nazarov, 1975 Astroentactinia sp.?}

Табл. I, фиг. 4 ; табл. II, фиг. 5

О пи с яни е. Раковина сферическая, по-видимому, с многочисленными внешними основными иглами. У экземпляров с сохранившимися иглами они короткие, конусовидные, иногда дихотомически разветвленные в дистальной части. Оболочка раковины пронизана разнообразными по форме и размерам порами.

Р а змеры (в микронах). Диаметр сферы 112-161; толщина ее 10 , длина основных игл до 40; диаметр их в основании $12-18$; диаметр пор $4-16$.

С р а нени е. Описанные экземпляры отличаются от среднеордовикских видов Astroentactinia отсутствием второстепенных игл, хотя это может зависеть от сохранности, небольшими размерами, а также очень разнообразной формой пор.

3 а м е а ния. Строение внутреннего каркаса не ясно: представлен ли он многогранником или спикулой, и неизвестно число лучей (шесть и более), связанных с основными иглами.

Р асп ростр анение. Верхний ордовик (ашгилл), сауньяская пачка набалаского горизонта (FIaS) Эстонии.

Местонахождение и м а ери ал. Скв. Эйкла, глубина 282,5 м; 2 целых экземпляра и фрагменты раковин. 
М янниль Р. М. История развития Балтийского бассейна в ордовике. Таллин, 1966.

М янниль Р. М. Распределение граптолоидей в карбонатных отложениях ордовика Прибалтики. - В кн.: Граптолиты и стратиграфия. Таллин, 1976, 105-118.

Н а з а ро в Б. Б. Радиолярии нижнего-среднего палеозоя Казахстана. М., 1975 (Тр. ГИН АН СССР, вып. 275).

Н а з аров Б. Б., Попов Л. Е. Стратиграфия и фауна кремнисто-карбонатных толщ ордовика Казахстана. М., 1980 (Тр. ГИН АН СССР, вып. 334).

$\mathrm{O}$ расп п льд А. Литологическая характеристика пиргуского горизонта в Южной Эстонии. - Уч. зап. Тартуского гос. университета. Тр. по геологии, VII. Тарту, $1975,14-32$.

Решения Межведомственного регионального стратиграфического совещания по разработке унифищированных стратиграфических схем Прибалтики, 1976 г. Л., 1978.

Bergström, S. M. The oldest known well preserved radiolarians from North America. - Geol. Soc. Amer., Abstracts with Programs, 1974, 5, 491.

D u ncham, J. B., Murp.hy, M. A. An occurrence of well preserved Radiolaria from Upper Ordovician (Caradocian), Eureka County, Nevada. - J. Paleontol., 1976, $50,882-887$.

E is en a ck, A. Die Mikrofauna der Ostseekalke. 1. Chitinozoen, Hystrichosphären. N. Jb. Geol. Paläont., Abh., 1965, 123, 115-149.

E is en a ck, A. Foraminiferen aus dem Ordovicium und Gothlandium des Baltischen Gebietes. - N. Jb. Geol. Paläont., Abh., 1967, 128, 244-274.

Eisena ck, A. Die Mikrofauna der Ostseekalke (Ordovizium). 3. Graptolithen, Melanoskleriten, Spongien, Radiolarien, Problematika nebst 2 Nachträgen über Foraminiferen und Phytoplankton. - N. Jb. Geol. Paläont., Abh., 1971, 137, 337-357.

Fortey, R. A., Holdsworth, B. K. The oldest known well-preserved Radiolaria. Bull. Soc. Paleontol. Italia, 1971, 10, 35-41.

$\mathrm{H}$ in d e, G. J. Notes on Radiolaria from the Lower Paleozoic rocks (Llandeilo-Caradoc) of South Scotland. - Ann. Mag. Nat. Hist., Ser. 6, 1890, 40-59.

I g o, H., Ad a chim, S., Furutani, H., Nish i a ma, H. Ordovician fossils first discovered in Japan. - Proc. Japan Acad., 1980, 56, Ser. B, 499-503.

$\mathrm{Nōlvak}$, J. Chitinozoans in biostratigraphy of the northern East Baltic Ashgillian. A preliminary report. - Acta Palaeont. Polon., 1980, 25, 253-260.

Геологический институт

Академии наук СССР

\author{
Ннститут геологии \\ Академии наук Эстонской ССР
}

Поступила в редакцию 2/XII 1981

\section{B. NAZAROV, J. NOLVAK}

\section{EESTI OLEMORDOVIITSIUMI RADIOLAARE}

Nabala lademe saunja kihistiku (Eikla ja Kaugatuma puursüdamikus) ning vormsi ja pirgu lademe piirikihtide (Viljandi puursüdamikus) peitkristallilistest lubjakividest on kirjeldatud 4 ümberkristalliseerunud karkassiga radiolaariliiki.

\section{B. NAZAROV, J. NOLVAK}

\section{RADIOLARIANS FROM THE UPPER ORDOVICIAN OF ESTONIA}

Rare radiolarians with recrystallized (pyritic or goethitic) framework are found only in calcilutites of the Estonian Upper Ordovician.

\section{Entactinia eiklaensis Nazarov, sp. n.}

$$
\text { Pl. I, Figs } 1-3
$$

A small spherical Entactinia with excentrically located internal framework. The six basic conical spines gradually taper from the base toward the distal end. The secondary spines are of a different length. The outer shell is penetrated by angular-oval pores. 
The inner framework represents a rounded hexahedron, from the angles of which extend six hollow rays.

\section{Haplentactinia baltica Nazarov, sp. $\mathrm{n}$. \\ Pl. II, Figs 2-4}

Large irregularly spherical shell with six massive spines. The spines are evidently an immediate continuation of the rays of an internal spicule. The spines have bnanched apophyses approximately at the same distance connected with adjacent apophyses, forming a coarse irregular (or isometric) shell with large cells.

\section{Polyentactinia ? estonica Nazarov, sp. n,}

Pl. II, Fig. 1

Spherical shell with numerous short basic spines broadened at the base. The small secondary spines have the form of sharp teeth. Almost all basic spines are connected by means of adjacent thick rods, in consequence of which the outer shell looks as if divided into additional segments. The inner structure is not clear.

\section{Astroentactinia sp. ?}

Pl. I, Fig. 4; Pl. II, Fig. 5

Spherical shell with evidently numerous basic spines. The spines are short, conical, sometimes branched in the distal part. Outer shell perforated by different pores. The structure of the internal framework is not clear. 